\title{
TAXATION OF THE INCOME ARISING FROM THE RIGHT TO CLAIM OBTAINED FROM PRE-PAID HOUSING SALES IN THE SCOPE OF INCOME TAX CODE
}

\author{
Aylin ARMAĞAN ${ }^{1} \quad$ Ali Yaşar ÇELIKEL ${ }^{2}$
}

\begin{abstract}
Pre-paid housing sales contract is a consumer contract between the consumer and the seller. This contract is mostly made in the form of preliminary property sales contract. Right to claim between the parties will be arised with this contract. Therefore, it is also possible for the consumer to transfer this right.

It is controversial whether the income obtained from the transfer of this right will be taxed under the Income Tax Law. There are three main views on this issue, which were discussed in the doctrine before. According to the first, this gain is a capital gain. Secondly, this gain is an occasional commercial gain. According to the last opinion, this gain cannot be evaluated under the Income Tax Law and therefore cannot be taxed. Within the scope of this study, these views in the doctrine were examined.

One of the results achived in this subject is that the terms are not in line with the terminology of civil law. In fact, the concept of "the right to buy housing" should be corrected as the right to claim. Also it is concluded that the income obtained from the transfer of the claim will not be considered as an capital gain within the scope of of the Income Tax Code. The expansion of the article of the law to include this gain, is primarily against the principle of the legality of the tax which sourced from the Constitution. Finally, it is stated that this gain cannot be described as occasional commercial gain if it is obtained from the preliminary property sales contract which is risen from the pre-paid housing sales. Since only the consumer can be a party of a pre-paid housing sale, this prevents all transactions from being considered as commercial.
\end{abstract}

Keywords: pre-paid housing sales contract, preliminary property sales contract, capital gain, occasional commercial gain

JEL Code: K11, K12, H24

\section{Introduction}

Over the past two decades, the economy of Turkey the economy of our country has been largely based on the construction sector. The grievances encountered in the construction sector have required the protection of buyers. As a result of this understanding, immovable properties, contrary to the comparative law and the European Union Directives, had included in consumer law with amendments made in 2003. However, these amendments were not sufficient, and the new consumer law came into force in 2014 specifically in order to harmonize the other provisions of the consumer law with the EU Consumer Law regulations.

Pre-paid housing sales contracts regulated in this code in detail. Pre-paid housing sales contracts enable the consumers to obtain the real estates that are not built in return for the appropriate

1 Res. Asst., Altınbaş University, Faculty of Law, Division of Fiscal Law, aylin.armagan@altinbas.edu.tr

2 Res. Asst., Altınbaş University, Faculty of Law, Division of Civil Law, ali.celikel@altinbas.edu.tr 
costs, while the sellers also have the opportunity to complete their contract by financing the sales without fulfilling their contractual obligations.

Pre-paid housing sales contracts can be made in the form of sales at the land registry or preliminary contract for sale at the notary public. However, this contract between the consumer and the seller is mostly made in the form of the preliminary sales contract. Although the goal of consumers is to have the houses they dreamed of, it is possible that they can transfer the right to claim which is obtained with the preliminary sales contract within the framework of the assignment of claim. The issue we discussed in our study is whether the assignment of the claim arising from the preliminary sales contract is a taxable income under the Income Tax Law. During this discussion, whether the earnings of the real person from transferred right to claim, is a value increase gain or is it a commercial gain will be analyzed.

\section{Pre-Paid Housing Sale}

\subsection{General Background}

In the first referral text of the Law on the Protection of Public Consumers (Law No. 4077 on Consumer Protection), immovables were outside the scope of the consumer law. With the radical amendment made by Law No. 4822 in 2003, immovable properties used as domicile or for holiday purposes were included in the consumer law by taking into account the concept of goods. However, despite the amendment made by Law no. 4822, this type of contract continued to be mentioned in practice with different names such as sales from the land or sales from the project, and legal regulations did not prevent the increase of the number of consumers who con not claim their houses and lost their investments. Prepaid housing sales contracts (PHSC) are regulated in detail in Turkish Law with the Law no. 6502 Consumers Protection Code (CPC) and the Regulation on Pre-paid Housing Sales (hereafter will be referred as Regulation) as a result of the need to eliminate the unjust treatment by protecting the consumers in an effective manner.

PHSC, is defined as " $a$ contract for which the consumer has to pay the price of a residential real estate in advance, and then the seller undertakes to hand over or transfer the immovable to the consumer after the full or partial payment of the price." in Law n. 6502 art. 40 and the Regulation art. 4/ğ.

It is seen that the legislator shaped the PHSC on four elements: the time of performance, consumer, seller and housing. The most important concept to be defined within the scope of this study is the consumer. The notion of consumer is defined in Law no. 6502 "as a natural or a legal person who is acting without the commercial or professional intent". This definition has been preserved in the Regulation art. 4/i. Therefore, these immovables must be purchased for personal purposes such as housing without any commercial or professional needs. (Özmen \& Vardar Hamamcıoğlu, 2016: 16; Makaracı, 2015: 242; Acar, 2015: 13).

\subsection{Preliminary Sales Contract}

According to art. 41 of PCP, pre-paid housing sales can be drafted in two types of contracts. These are immovable property sales contract at the land registry or preliminary contract of sale of an immovable property at the notary public. (Çabri, 2018: 93; Gümüş, 2014: 249-250; Aslan, 2014: 456). However, in practice preliminary sales contract is frequently encountered. 
The preliminary sales contract which has significant importance in our study, is a contract that oblige to make the necessary will statements to the parties of the contract in order to make an immovable sales contract in the future. (Akipek \& Akıntürk, 2009: 472; Eren, 2014: 223). As it is generally accepted by doctrine and supreme court decisions, it is a precontract (Tekinay \& Akman \& Burcuoğlu \& Altop, 1989: 691-692; Kocayusufpaşaoğlu, 1959: 67; Akipek \& Akıntürk, 2009: 472; Eren, 2016: 235; 1986: 6; Ayrancı, 2006: 40; Sirmen, 2017: 363; Özmen \& Vardar Hamamcıoğlu, 2016: 37; İnal, 2011: 2017-208). Here, the obligation of the parties is to make a sales contract at the land registry office, but not to deliver the property. With the preliminary sales contract, the parties shall have the right to claim arose from the contract and this right may assign to a third person according to the provision granted in the Turkish Code of Obligations art. 183 et al. (Eren, 2014: 223). The legal problem to be addressed in our study is that whether the income to be obtained in case of assignment of claim can be taxed under the Income Tax Code (ITC).

\section{Evaluation of the Assignment of Claim Arose from PHSC in Terms of Income Tax}

\subsection{Legal Framework}

It is controversial whether this income can be taxed or not if a real person makes a profit by assigning a claim to a third party. When ITC rep. art. 80/6 and art.70/4 interpreted together, it is accepted that, if a right registered as immovable property transferred within five years from the date of acquisition, the gain is recognized as income and taxed according to the provisions of the ITC.

\subsection{Existing Remarks}

According to one opinion, it is necessary to take into account any benefits that are provided in return for disposal and have a monetary value in the framework of the ITC (Dikmen, 2010: 345; Alkın \& Şenses, 2014: 106). The fact that the right is a registerable right is sufficient in terms of taxation (Demireller, 2004: 40). Therefore, it is possible to tax the gain obtained from the assignment of claim. (Dikmen, 2010: 40; Alkış \& Şenses, 2014: 106). Otherwise, it is stated that it is possible for taxpayers to avoid tax in such ways (Dikmen, 2010: 39).

Opposite opinion is that it does not qualify as gain obtained from assignment of claim as capital gain (Akın \& Kara, 2018: 147; Demireller, 2004: 92). According to this opinion the provision of the law states that only registered rights can be taxed under the ITC rep. art. 80. The scope of the provision cannot be extended as "registerable right" when it states, "registered rights" (Akın \& Kara, 2018: 147: Demireller, 2004: 93).

According to another opinion, the gain arising from the transfer of assignment of claim is not included in the capital gain tax but falls within the scope of incidental commercial gain (Akın \& Kara, 2018: 147). Thus, the gains obtained from the sale of the immovable property rights without an element of continuity should be qualified as incidental gain under this provision. On the other hand, another author mentions the difficulty of identifying this process as an incidental transaction (Demireller, 2004: 95). 


\subsection{Assessment}

The right to claim can not be registered within the framework of the principles of the property law. Because in the light of the Turkish Civil Code art. 705, 780, 840 and 856 it is seen that only rights in rem will be registered. The right to claim arise from preliminary sales contract which is not a right in rem, but a relative right.

At this point, it should be emphasized that the concept "registrerable" is inaccurate. First of all, it is not possible to register a right to claim, or any othe rights arised from contracts. Because it is exhaustively listed that only rights in rem which are ownership and limited rights in rem can be registered in TCC. In our opinion, the authors in this view mistakenly confuse the establishment of registration with the notion of annotation. Because the rights that can be annotated is listed in Turkish Civil Code and in various laws within the scope of numerus clausus pricinple. The preliminary sales contract and the right to claim arise from it is can be annotated in the land register. However, annotation will not change the fact that the gain obtained from the assignment of claim is still not registered, therefore is not in the scope of capital gain according to ITC rep. art. 80.

The extension of the aforementioned provision to include the right to claim, which is not a right in rem, shall result in a violation of the principle of legality of the taxation arise from the Constitution. The principle of the legality of the tax requires not only the taxation, but also all duties and procedures related to taxation regulated through the laws (Güneş, 2014: 133; Öncel \& Kumrulu \& Çağan, 2018: 49; Koyuncu, 2016: 154). According to the Constitutional Court, the basic constituent elements of the tax such as subject, base, rate, accrual, and statutory limitation of tax must be established by tax laws (Saban, 2015: 63). The subject of the tax, which is one of the founding elements of the tax, is the goods, actions, cases, legal or commercial transactions, economic values or social situations on which the tax is taken (Güneş, 2014: 134; Öz, 2004: 72). However, in ITC provision which says that the gain arose from transfer of registered rights are taxable as capital gain, is definite in a manner that will not leave any room for expansion. For these reasons, it does not seem possible to tax the gain from the transfer of the right to claim as a capital gain.

\section{Conclusion}

In conclusion when the provisions of ITC are examined, it is not possible to evaluate the gain obtained from the assignment of claim, as capital gain. Because provisions of ITC only the gain obtained from the transfer of registered rights shall be considered as the value increase gain. In the case of the transfer of the right to claim obtained in accordance with the preliminary sales contract, this right is not a registered right and does not fall under the scope of this provision. The attempt to expand the provision to include this gain, will result in a violation of the principle of the legality of the taxation.

Secondly, it is not possible in the framework of the existing legal regulations that the gain obtained from the assignment of claim arising from the PHSC to be taxed either as commercial or incidental commercial gain. Because, in order to be able to mention the existence of a PHSC, in the context of CPC, one of the parties must have the title of consumer. The real person who has the title of consumer must have acquired this immovable property non-professionally and non-commercially. Because the consumer is acting for purposes which are outside his/her 
trade, profession or commerce and for this reason the assignment of claim cannot be seen as a commercial gain.

As a result of these explanations and interpretations the gain obtained from the assignment of claim obtained through PHSC, is not covered by the ITC regardless of the acquisition method and the date of acquisition.

\section{References}

Acar, H. (2015). “6502 Sayılı Tüketicinin Korunması Hakkında Kanun Çerçevesinde Ön Ödemeli Konut Satiş Sözleşmesi”, Fatih Üniversitesi Hukuk Fakültesi Dergisi, C:3 (1), pp. 11-40.

Akın, E. \& Kara, M. (2018). “Konut Projelerindeki Rantın Vergilendirilmesi: Gayrimenkul Satış Vaadi Sözleşmesinden Doğan Konut Alım Hakkının Devri Vergiye Tabi Midir?” Vergi Dünyası Dergisi, S. 437, pp. 145-149.

Akipek, J. \& Akıntürk, T. (2009). Eşya Hukuku, İstanbul, Beta Yayınevi.

Alkış, S \& Şenses. N (2014). “Gayrimenkul Satış Vaadi Sözleşmesinden Doğan konut Alım Hakkını Devredenlerin Vergi Kanunları Karşısındaki Durumu", Vergi Dünyası Dergisi, S. 395, pp. 102-109.

Aslan, i. Y. (2014). 6502 Sayılı Kanun'a Göre Tüketici Hukuku, 4. Baskı, Bursa, Ekin Basım Yayın Dağıtım.

Ayrancı, H. (2006). Ön Sözleşme, Ankara, Yetkin Yayınları.

Çabri, S. (2018). "Ön Ödemeli Konut Satışı Sözleşmeleri”, Inşaat Sektöründe Tüketici Hukuku Uygulamaları, (Ed.) Tokbaş, H. \& Kurşun, A. S., 2. Baskı, İstanbul, Aristo Yayınevi, pp. 91-159.

Çenberci, M. (1986). Gayrimenkul Satş̧ Vaadi, 3. Baskı, Ankara, Olgaç Matbaası.

Demireller, A. (2004). "Gayrimenkul Satış Vaadi Sözleşmesiyle Elde Edilen Konut (Daire) Alın Hakkının Devredilmesi Gelir Vergisinin Konusuna Girer mi?", Vergi Dünyası Dergisi, S. 392, pp. 89-97.

Dikmen, M. B. (2010). "Gayrimenkul Satış Vaadi Sözleşmesinden Doğan Hakkını Tapu Verilmeden Önce Devredenler Açısından Değer Artış Kazancı Ortaya Çıkar mı?”, Vergi Dünyası Dergisi, S. 345, pp. 36-41.

Eren, F. (2014). Borçlar Hukuku Özel Hükümler, Ankara, Yetkin Yayınları.

Eren, F. (2016). Mülkiyet Hukuku, 4. Baskı, Ankara, Yetkin Yayınları.

Gümüş, M. A. (2014). 6502 Sayılı Tüketicinin Korunması Hakkında Kanun Şerhi, C.1, İstanbul, Vedat Kitapçılık.

Güneş, G. (2014). Verginin Yasallığı ilıkesi, İstanbul, On İki Levha Yayınları.

İnal, E. (2011). Sonuca Katılmalı Sözleşme Kavramı ve Gelir Paylaşımlı Inşaat Sözleşmesi, İstanbul, Oniki Levha Yayıncılık.

Kocayusufpaşaoğlu, N. (1959). Türk Medeni Hukukunda Gayrimenkul Saţ̧ Vaadi, İstanbul, Sulhi Garan Matbaası. 
Makaracı, A. (2015). “6502 Sayılı Tüketicinin Korunması Hakkında Kanun Uyarınca Ön Ödemeli Konut Satışı”, Yeni Tüketici Hukuku Konferansı, İstanbul, Oniki Levha Yayıncılık, pp. 239-259.

Öncel, M. \& Kumrulu, A. \& Çağan, N. (2018). Vergi Hukuku, Ankara, Turhan Kitapevi,

Koyuncu, C. (2016). Anayasal Vergilendirme Ilkeleri, Bursa, Ekin Yayınları.

Saban, N. (2015). Vergi Hukuku, İstanbul, Beta Yayınları.

Öz, E. (2004). Vergilendirmede Kanunilik ve Türk Vergi Sistemi, Ankara, Gazi Kitapevi,

Oktar, S. A. (2018). Türk Vergi Sistemi, İstanbul, Türkmen Kitapevi.

Özmen, E. S. \& Vardar Hamamcıoğlu, G. (2016). Ön Ödemeli Konut Satış Sözleşmesi, İstanbul, Oniki Levha Yayıncılık.

Sirmen, L. (2017). Eşya Hukuku, 5. Bası, Ankara, Yetkin Yayınları.

Tekinay, S. S. \& Akman, S. \& Burcuoğlu, H. \& Altop, A. (1989). Eşya Hukuku C. 1, 5. Bası, İstanbul, Filiz Kitabevi.

Yıldırım, M. (2015). “Gayrimenkullerin Elden Çıkarılmasında Doğan Kazançların Vergilendirilmesi”, Vergi Sorunları Dergisi, S. 318, pp. 32-37. 